\title{
Pengaruh Model Pembelajaran Kooperatif Tipe CO-OP CO-OP terhadap Kemampuan Pemecahan Masalah Statistika Peserta Didik Kelas VIII SMP Negeri 1 Minasate'ne Kab. Pangkep
}

\author{
Nurmahwati $^{1}$, Rahmawati ${ }^{2}$ \\ ${ }^{1}$ Jakarta Intensif Learning Center (JILC), Cabang Pangkep \\ ${ }^{2}$ Universitas Muslim Maros \\ ${ }^{1}$ nurmahwatiali@gmail.com \\ 2 nyoled@umma.ac.id
}

\begin{abstract}
ABSTRAK
Penelitian ini merupakan penelitian eksperimen semu (quasi eksperiment) yang bertujuan untuk mengetahui pengaruh dari penerapan model pembelajaran kooperatif tipe co-op co-op terhadap kemampuan pemecahan masalah statistika peserta didik kelas VIII SMP Negeri 1 Minasate'ne Kab. Pangkep. Metode penelitian ini adalah penelitian kuantitatif dengan nonequivalent control grup design, dimana terdapat dua kelompok belajar. Kelompok eksperimen diajar menggunakan model pembelajaran kooperatif tipe co-op co-op, dan kelompok kontrol menggunakan model pembelajaran Konvensional. Populasi dalam penelitian ini adalah peserta didik kelas VIII SMP Negeri 1 Minasate'ne dan pengambilan sampel dilakukan dengan teknik purposive sampling. Sampel dalam penelitian ini adalah peserta didik kelas VIII B sebagai kelas eksperimen dan kelas VIII D sebagai kelas kontrol. Pengumpulan data menggunakan tes kemampuan pemecahan masalah yang telah divalidasi oleh ahli. Hasil penelitian ini dianalsis secara deskriptif dan inferensial dengan uji normalitas dan uji homogenitas sebagai uji prasyarat analisis dan uji $t$ sebagai uji hipotesa. Hasil analisis deskriptif menunjukkan bahwa rata-rata posttest pada kelas kontrol adalah 73,59 dengan standar deviasi 7,243 sedangkan rata-rata posttest pada kelas eksperimen adalah 82,69 dengan standar deviasi 8,177. Berdasarkan uji $t$, diperoleh nilai sig (2tailed) $<1 / 2 \alpha(0,000<0,025)$ yang menunjukkan adanya pengaruh model pembelajaran kooperatif tipe co-op co-op terhadap kemampuan pemecahan masalah statistika peserta didik kelas VIII SMP Negeri 1 Minasate'ne, melalui perhitungan effect size cohen's $d$ diketahui bahwa besar pengaruhnya adalah 1,199 yang berada pada kategori tinggi dengan persentase $86 \%$ sehingga dapat disimpulkan bahwa Penerapan model pembelajaran kooperatif tipe co-op co-op memberikan pengaruh positif terhadap kemampuan pemecahan masalah statistika peserta didik SMP Negeri 1 Minasate'ne Kab. Pangkep.
\end{abstract}

Kata Kunci: Model Pembelajaran Kooperatif, tipe Co-op Co-op, Matematika Statistika

\begin{abstract}
This research is a quasi-experimental research that aim to know the influence of cooperative learning model type co-op co-op to statistical problem solving skills participants of grade VIII Smp Negeri 1 Minasate'ne Kab. Pangkep.. The method of this research is quantitative research with nonequivalent control grup design, where there are two groups. The experimental group was taught using cooperative learning model type co-op co-op, and control groups was taught was using conventional model. Population of this research is the students of grade VIII Smp Negeri 1 Minasate'ne Kab. Pangkep with purposive sampling. Sample of this research is class VIII B as experimental class and class VIII D as control class. Data collection using a test problem solving skills that has been validated by an expert. Research result to analyzed descriptively and inverensial with normality test and homogenity test as prerequisite test and $t$ test as hypothesis testing. Deskriptive analysis result show that average posttest value of control class is 73,59 with
\end{abstract}


standard deviation 7,243 and the average posttest value of experimental class is 82,69 with standard deviation is 8,177. Based on t test, obtained sig. (2-tailed) $<1 / 2 \alpha(0,000<0,025)$ indicating that there is an influence of cooperative learning model type co-op co-op to statistical problem solving skills participants of grade VIII Smp Negeri 1 Minasate'ne Kab. Pangkep, through effect size cohen's d calculation knows that the influene is 1,199 in the high category with the persentage is $86 \%$ it can be conclude that cooperative learning model type co-op co-op give influence to statistical problem solving skills participants of grade VIII SMP Negeri 1 Minasate'ne Kab. Pangkep

Keywords: Cooperative Learning Model, Type Co-Op Co-Op, Statistical Mathematics.

\section{A. PENDAHULUAN}

Matematika merupakan materi dasar dari aplikasi dalam kehidupan pelajaran yang mendapat perhatian sehari-hari dan merupakan induk dari khusus, karena matematika adalah semua jenis ilmu kealaman, tanpa matematika sebuah bangsa tidak akan mampu menyapa alam semesta secara proporsional dan wajar.

Banyak orang yang menilai bahwa matematika adalah pelajaran yang sulit dan tidak mudah dikuasai, Peserta didik merasa kurang memiliki minat yang tinggi bila menjumpai soal - soal matematika yang sulit dan bahkan cenderung untuk menghindarinya. Ketika fakta ini terungkap, alasan mendasar mengapa matematika dianggap pelajaran yang menyulitkan adalah karena faktor dalam diri peserta didik itu sendiri. Mereka telah tersugesti dengan pikirannya sendiri atau bahkan mereka mensugesti pikirannya sendiri kalau matematika itu menyulitkan. Akhirnya tidak ada sedikit pun usaha untuk mengerjakan sendiri dan lebih memilih untuk mencontek temannya.

Selain itu, salah satu penyebab pelajaran matematika dikatakan sulit oleh para peserta didik juga karena pada dasarnya banyak konsep dan prinsip dalam matematika yang sulit dikuasai oleh peserta didik. Konsep dan prinsip yang tidak dikuasai tersebut mengakibatkan peserta didik tidak memiliki keterampilan dalam menyelesaikan soal-soal matematika dengan baik. Akibatnya kemampuan dalam memecahkan masalah matematika peserta didik tidak tercapai.

Menurut Polya (Wahyudi dan Anugraheni, 2017) pemecahan masalah merupakan suatu usaha untuk menemukan jalan keluar dari suatu kesulitan dan mencapai tujuan yang tidak dapat dicapai dengan segera. Atau dengan kata lain pemecahan masalah merupakan proses bagaimana mengatasi suatu persoalan atau pertanyaan yang bersifat menantang yang tidak dapat diselesaikan dengan prosedur rutin yang sudah sudah diketahui. Menurut Hudoyo (Wahyudi dan Anugraheni, 2017) pemecahan masalah pada dasarnya adalah proses yang ditempuh oleh seseorang untuk menyelesaikan masalah yang dihadapinya sampai masalah tidak lagi menjadi masalah. Berdasarkan pendapat tersebut, maka dapat didefinisikan bahwa pemecahan masalah merupakan suatu usaha untuk menemukan jalan keluar dari suatu kesulitan atau masalah yang tidak rutin 
sehingga masalah tersebut tidak lagi menjadi masalah lagi.

Slavin (Erhadap, 2017) menyatakan model pembelajaran coop co-op adalah sebuah bentuk group investigation yang cukup familiar dimana model ini menempatkan tim dalam kooperasi antara satu dengan yang lainnya untuk mempelajari sebuah topik di kelas. Model pembelajaran ini melatih peserta didik untuk bertanggung jawab dan bekerja keras menyelesaikan topik kecil yang dipercayakan oleh tim, setelah itu memaparkan dan mendiskusikan dalam kelompok kecil. Hal ini dapat membuat peserta didik lebih kreatif dalam mengeluarkan ide-ide, saling berbagi pengalaman dan bekerja sama dalam kelompok kecil untuk pemecahan suatu topik, kemudian mendiskusikan dalam satu tim untuk menggali lebih topik yang telah dipilih dan memaparkan di kelas dalam bentuk presentasi dan diskusi.

Berdasarkan informasi yang diperoleh peneliti dari guru matematika SMPN 1 Minasate'ne, pembelajaran yang sering kali digunakan oleh guru adalah pembelajaran searah yaitu informasi atau ide diberikan langsung oleh guru sedangkan peserta didik itu hanya pasif dalam menerimanya. Pembelajaran tersebut tidak melibatkan peserta didik secara aktif, mereka tidak diberi kesempatan untuk membangun pengetahuan mereka serta tidak adanya keberanian untuk mengungkapkan pendapat atau gagasannya. Hal ini memicu kurangnya kemampuan pemecahan masalah matematika peserta didik. Jadi, salah satu alternatif model pembelajaran yang mampu meningkatkan minat belajar untuk memecahkan masalah matematika peserta didik yaitu dengan menggunakan model pembelajaran kooperatif tipe co-op co-op.

\section{B. METODOLOGI PENELITIAN}

Penelitian yang akan dilaksanakan menggunakan pendekatan kuantitatif dengan jenis penelitian quasi eksperimen (eksperimen semu).

Desain ini mempunyai kelompok kontrol, tetapi tidak dapat berfungsi sepenuhnya untuk mengontrol variabel-variabel luar yang mempengaruhi pelaksanaan eksperimen. Walaupun demikian desain ini lebih baik dari preexperimental design. Quasi eksperimen digunakan karena pada kenyataannya sulit mendapatkan kelompok kontrol yang digunakan untuk penelitian. (Sugiyono, 2009)

Penelitian ini dilakukan pada dua kelas dengan perlakuan yang berbeda. Kelas eksperimen diberikan perlakuan dengan menggunakan model pembelajaran kooperatif tipe co-op co-op, sedangkan kelas kontrol menggunakan model pembelajaran konvensional.

Desain penelitian ini menggunakan rancangan penelitian Nonequivalent Control grup Design. Dengan desain ini, baik kolompok eksperimental maupun kelompok kontrol dibandingkan, kendati kelompok tersebut dipilih dan ditempatkan tanpa melalui randomisasi (Emzir, 2011). Rancangan penelitian tersebut dinyatakan sebagai berikut: 
Tabel 1. Nonequivalent Control Grup Design

\begin{tabular}{cccc}
\hline Kelas & Pretest & Perlakuan & Posttest \\
\hline Eksperimen & $\mathrm{O}_{1}$ & $\mathrm{X}$ & $\mathrm{O}_{2}$ \\
\hline Kontrol & $\mathrm{O}_{3}$ & - & $\mathrm{O}_{4}$ \\
\hline
\end{tabular}

Keterangan :

$\mathbf{O}_{1}$ : tes awal kelas eksperimen (pretest)

$\mathbf{O}_{1}$ : tes akhir kelas eksperimen (posttest)

$\mathbf{O}_{1}$ : tes awal kelas kontrol (pretest)

$\mathbf{O}_{1}$ : tes akhir kelas kontrol (posttest)

X : Model Pembelajaran tipe co-op co-op

\section{HASIL PENELITIAN}

Tabel 2. Analisis Deskriptif data pretest Kelas Kontrol dan Kelas Eksperimen

\begin{tabular}{lrrr}
\hline & $\begin{array}{r}\text { Pretest } \\
\text { Kontrol }\end{array}$ & $\begin{array}{r}\text { Pretest } \\
\text { Eksperimen }\end{array}$ \\
\hline \multirow{2}{*}{ Mean } & Valid & 29 & 29 \\
\cline { 2 - 4 } & Missing & 0 & 0 \\
\hline Std. Error of Mean & 1,058 & 1,100 \\
\hline Median & 43,00 & 46,00 \\
\hline Mode & 48 & 39 \\
\hline Std. Deviation & 5,699 & 5,923 \\
\hline Variance & 32,475 & 35,076 \\
\hline
\end{tabular}

\begin{tabular}{lrr}
\hline & $\begin{array}{r}\text { Pretest } \\
\text { Kontrol }\end{array}$ & $\begin{array}{r}\text { Pretest } \\
\text { Eksperimen }\end{array}$ \\
\hline Range & 21 & 25 \\
\hline Minimum & 35 & 31 \\
\hline Maximum & 56 & 56 \\
\hline Sum & 1283 & 1281 \\
\hline
\end{tabular}

(Sumber: Hasil analisis dengan SPSS Versi 24)

Tabel 3. Analisis Deskriptif data posttest kemampuan pemecahan masalah statistika Peserta Didik Kelas Kontrol dan Eksperimen

\begin{tabular}{lrrr}
\hline & & $\begin{array}{r}\text { Posttest } \\
\text { Kontrol }\end{array}$ & $\begin{array}{r}\text { Posttest } \\
\text { Eksperimen }\end{array}$ \\
\hline $\mathrm{N}$ & Valid & 29 & 29 \\
\cline { 2 - 4 } & Missing & 0 & 0 \\
\hline Mean & 73,59 & 82,69 \\
\hline Std. Error of Mean & 1,345 & 1,518 \\
\hline Median & 76,00 & 83,00 \\
\hline Mode & 76 & 77 \\
\hline Std. & 7,243 & 8,177 \\
Deviation & 52,466 & 66,865 \\
\hline Variance & 28 & 33 \\
\hline Range & 60 & 65 \\
\hline Minimum & 88 & 98 \\
\hline Maximum & 2134 & 2398 \\
\hline Sum & & \\
\hline
\end{tabular}

(Sumber: Hasil analisis dengan SPSS Versi 24)

Tabel 4. Hasil Uji Normalitas

\begin{tabular}{lcccc}
\hline \multicolumn{1}{c}{ Sumber } & Nilai $\boldsymbol{p}(\mathbf{s i g})$ & $\boldsymbol{\alpha}$ & Keputusan & Kesimpulan \\
\hline Pretest kontrol & 0,187 & 0,05 & Nilai $p>\alpha$ & Normal \\
\hline Posttest kontrol & 0,238 & 0,05 & Nilai $p>\alpha$ & Normal \\
\hline Pretest eksperimen & 0,367 & 0,05 & Nilai $p>\alpha$ & Normal \\
\hline Posttest eksperimen & 0,744 & 0,05 & Nilai $p>\alpha$ & Normal \\
\hline
\end{tabular}

(Sumber: Hasil analisis dengan SPSS Versi 24)

Tabel 5. Hasil Uji Homogenitas Posttest Kelas Kontrol dan Kelas Eksperimen

\begin{tabular}{llrrrr}
\hline & & Levene Statistic & df1 & df2 & \multicolumn{1}{c}{ Sig. } \\
\hline \multirow{4}{*}{$\begin{array}{l}\text { Kemampuan } \\
\text { Pemecahan Masalah }\end{array}$} & Based on Mean & 0,412 & 1 & 56 & 0,524 \\
\cline { 2 - 6 } & Based on Median & 0,511 & 1 & 56 & 0,477 \\
\cline { 2 - 7 } & $\begin{array}{l}\text { Based on Median and } \\
\text { with adjusted df }\end{array}$ & 0,511 & 1 & 55,763 & 0,478 \\
\cline { 2 - 7 } & Based on trimmed mean & 0,406 & 1 & 56 & 0,527 \\
\hline
\end{tabular}


Tabel 6. Hasil Uji Independent Sample t test Posttest Kelas Kontrol dan Kelas Eksperimen

\begin{tabular}{|c|c|c|c|c|c|c|c|c|c|c|}
\hline & & $\begin{array}{r}\text { Leve } \\
\text { Test } \\
\text { Equal }\end{array}$ & $\begin{array}{l}\text { ne's } \\
\text { for } \\
\text { ity of }\end{array}$ & & & t-test for & quality & f Means & & \\
\hline & & Varia & nces & & & & & & & \\
\hline & & $\mathbf{F}$ & Sig. & $\mathbf{T}$ & Df & $\begin{array}{c}\text { Sig. } \\
\text { (2tailed) }\end{array}$ & $\begin{array}{l}\text { Mean } \\
\text { Differ }\end{array}$ & $\begin{array}{l}\text { Std. Error } \\
\text { Differenc }\end{array}$ & $\begin{array}{r}95 \% \text { Cor } \\
\text { Interva } \\
\text { Diffe }\end{array}$ & $\begin{array}{l}\text { fidence } \\
\text { of the } \\
\text { ence }\end{array}$ \\
\hline & & & & & & & & & Lower & Upper \\
\hline & $\begin{array}{l}\text { Equal } \\
\text { variances } \\
\text { assumed }\end{array}$ & & & $-4,488$ & 56 & ,000 & $-9,103$ & 2,029 & $-13,167$ & $-5,040$ \\
\hline Nilai & $\begin{array}{l}\text { Equal } \\
\text { variances } \\
\text { not } \\
\text { assumed }\end{array}$ & ,412 & ,524 & $-4,488$ & 55,196 & ,000 & $-9,103$ & 2,029 & $-13,168$ & $-5,039$ \\
\hline
\end{tabular}

(Sumber: Hasil analisis dengan SPSS Versi 24)

Untuk mengetahui besar pengaruh dari model pembelajaran kooperatif tipe co-op coop terhadap kemampuan pemecahan masalah matematika peserta didik kelas VIII $t$ digunakan rumus cohen's sebagai berikut:

$$
d=\frac{\bar{x}_{t}-\bar{x}_{c}}{S_{\text {pooled }}} \times 100 \%
$$

dengan,

$d=$ cohen's effect size (besar pengaruh dalam persen)

$t=$ Mean treatment condition (rata-rata kelas eksperimen)

$c=$ Mean control condition (rata-rata kelas control)

spooled = Standart deviation (standar deviasi gabungan)

Untuk mengetahui nilai dari SMP Negeri 1 Minasate'ne pada materi statistika, maka dilakukan perhitungan Effect size cohen's $d$. Untuk mengetahui effect size pada uji $s_{p o}$ digunakan rumus berikut:

$$
s_{\text {pooled }}=\sqrt{\frac{\left(n_{1}-1\right) s d_{1}{ }^{2}+\left(n_{2}-1\right) s d_{2}{ }^{2}}{n_{1}+n_{2}}}
$$

dengan,

$S_{\text {pooled }}=$ standar deviasi gabungan

$n_{1} \quad=$ jumlah peserta didik kelas eksperimen

$n_{2} \quad=$ jumlah peserta didik kelas kontrol

$s d_{1}{ }^{2}=$ standar deviasi kelas eksperimen

$s d_{2}{ }^{2}=$ standar deviasi kelas kontrol

Setelah memperoleh nilai dari $d$, nilainya akan dicocokan pada tabel interpretasi cohen's untuk mengetahui standar pengaruh dan persentasenya.

$$
\begin{aligned}
s_{\text {pooled }} & =\sqrt{\frac{\left(n_{1}-1\right) s d_{1}^{2}+\left(n_{2}-1\right) s d_{2}^{2}}{n_{1}+n_{2}}} \\
& =\sqrt{\frac{(29-1) 8,177^{2}+(29-1) 7,243^{2}}{29+29}} \\
& =\sqrt{\frac{(28) 66,863+(28) 52,461}{58}}
\end{aligned}
$$




$$
\begin{aligned}
& =\sqrt{\frac{1872,164+1468,908}{58}} \\
& =\sqrt{\frac{3341,072}{58}} \\
& =\sqrt{57,604} \\
& =7,589
\end{aligned}
$$

Karena $S_{\text {pooled }}=7,589$, maka:

$$
\begin{aligned}
& d=\frac{\bar{x}_{t}-\bar{x}_{c}}{S_{\text {pooled }}} \times 100 \% \\
& d=\frac{82,69-73,59}{7,589} \times 100 \% \\
& d=\frac{9,1}{7,589} \times 100 \% \\
& d=1,199
\end{aligned}
$$

Jadi, nilai Effect size cohen'sd sebesar 1,199. Maka, diketahui bahwa besar pengaruh penerapan model pembelajaran kooperatif tipe co-op co- op terhadap kemampuan pemecahan masalah matematika peserta didik kelas VIII SMP Negeri 1 Minasate'ne pada materi Statistika adalah 1,199. berdasarkan tabel interpretasi nilai cohen's, nilai 1,199 berada pada kategori Tinggi dengan Percentil standing sebesar $86 \%$.

\section{PEMBAHASAN}

Pada bagian ini peneliti akan menjelaskan lebih lanjut mengenai hasil pengujian statistik deskriptif dan statistik inferensial terhadap data kemampuan pemecahan masalah matematika materi statistika yang diperoleh dari penelitian.

Berdasarkan analisis deskriptif, terlihat bahwa penerapan model pembelajaran kooperatif tipe co-op co-op memberikan pengaruh yang positif terhadap kemampuan pemecahan masalah matematika peserta didik. Hal tersebut ditunjukkan dengan nilai rata-rata kelas eksperimen yaitu 82,69 lebih tinggi daripada kelas kontrol yang menerapkan model pembelajaran konvensional dengan nilai rataratanya yaitu 73,59 yang diperoleh setelah kedua kelas tersebut diberikan tes kemampuan pemecahan masalah matematika dengan butir soal yang sama dan telah divalidasi.

Selain itu, analisis inferensial juga menunjukkan fakta bahwa uji $t$ sampel independent dengan taraf signifikansi $\alpha=0,05$, diperoleh nilai Sig (2-tailed) yakni 0,000. Karena Sig (2-tailed) $<\frac{1}{2} \alpha$ atau 0,025 , sesuai dengan kaidah pengujian hipotesis ini, maka diketahui bahwa terdapat pengaruh penerapan model pembelajaran kooperatif tipe co-op co- op terhadap kemampuan pemecahan masalah statistika peserta didik SMP Negeri 1 Minasate'ne Kab. Pangkep. Adapun pengaruh penerapan model pembelajaran kooperatif tipe co-op co- op diketahui dari Perhitungan effect cohn's d.

Apabila Effect size dari perhitungannya berada pada 0,8 sampai 2,0 maka Cohen's standard berada pada kategori tinggi, jika Effect size dari perhitungannya berada pada 0,5 sampai 0,7 maka Cohen's standard berada pada kategori sedang, dan apabila Effect size dari perhitungannya berada pada 0,2 sampai 0,4 maka Cohen's standard berada pada kategori rendah. Karena nilai dari effect cohn's $d$ yaitu 1,1, Berdasarkan tabel interpretasi nilainya 
berada pada kategori tinggi dengan persentase sebesar $86 \%$.

Proses pembelajaran yang menggunakan model pembelajaran kooperatif tipe co-op coop memiliki pengaruh yang positif dalam meningkatkan kemampuan pemecahan masalah matematika peserta didik. Hal ini karena dalam pembelajaran kooperatif tipe coop co-op peserta didik dituntut lebih aktif dalam kegiatan pembelajaran dimana suasana belajarnya juga menyenangkan sehingga tidak membuat peserta didik merasa tegang dan terpaksa dalam belajar. Kegiatan kerja kelompok ini dapat melatih peserta didik memiliki rasa tanggung jawab atas tugas yang mereka kerjakan serta menumbuhkan jiwa sosial yang selalu dapat bekerja sama dalam menyelesaikan masalah.

Fakta yang ditemukan peneliti di atas sesuai dengan pendapat (Maryanti, 2018) dalam penelitiannya yang menyatakan bahwa setelah diterapkan model pembelajaran kooperatif $\mathrm{Co}$ op co-op dengan pendekatan POE terdapat peningkatan terhadap kemampuan pemecahan masalah matematis Peserta didik.

Proses pembelajaran yang menggunakan model pembelajaran kooperatif Co-op co-op dengan pendekatan POE memiliki hasil lebih baik dalam meningkatkan kemampuan pemecahan masalah matematis Peserta didik dibandingkan dengan model pembelajaran konvensional. Berbeda dengan proses pembelajaran yang menggunakan model pembelajaran konvensional yang lebih berfokus pada guru, dan cenderung peserta didik hanya memperhatikan dan menerima. Berdasarkan uraian di atas, terlihat bahwa model pembelajaran kooperatif tipe co-op co-op memberikan dampak positif terhadap kemampuan pemecahan masalah matematika materi statistika dan keaktifan peserta didik yang kemudian mempengaruhi kemampuan pemecahan masalah matematikanya. Karena hasil analisis deskriptif dan inferensial menunjukkan bahwa kemampuan pemecahan masalah matematika peserta didik yang diajar menggunakan model pembelajaran kooperatif tipe co-op co-op lebih baik dibanding peserta didik yang diajar menggunakan model pembelajaran konvensional, maka dapat

disimpulkan bahwa penerapan model pembelajaran kooperatif tipe co-op co-op memberikan pengaruh positif terhadap kemampuan pemecahan masalah matematika materi Statistika khususnya menentukan mean, median, dan modus yang diajarkan pada penelitian ini yang disebabkan karena model pembelajaran tersebut mampu membangkitkan semangat belajar matematika peserta didik kelas VIII. B.

\section{E. PENUTUP}

\section{Kesimpulan}

Berdasarkan hasil penelitian dan pembahasan pada bab sebelumnya, maka dapat disimpulkan sebagai berikut :

a. Kemampuan pemecahan masalah statistika peserta didik SMP Negeri 1 Minasate'ne Kab. Pangkep yang menerapkan model 
pembelajaran kooperatif tipe coop co-op memperoleh rata-rata sebesar 82,69 lebih tinggi dibandingkan dengan rata-rata kemampuan pemecahan masalah statistika yang tidak menerapkan model pembelajaran kooperatif tipe co-op co-op sebesar 73,59. Dengan demikian, Penerapan model pembelajaran kooperatif tipe co-op co-op memberikan pengaruh positif terhadap kemampuan pemecahan masalah statistika peserta didik SMP Negeri 1 Minasate'ne Kab. Pangkep.

b. Pengaruh model pembelajaran kooperatif tipe co-op co-op terhadap kemampuan pemecahan masalah statistika peserta didik kelas VIII SMP Negeri 1 Minasate'ne Kab. Pangkep diketahui dari Perhitungan effect cohn's $d$. Apabila Effect size dari perhitungannya berada pada 0,8 sampai 2,0 maka Cohen's standard berada pada kategori tinggi, jika Effect size dari perhitungannya berada pada 0,5 sampai 0,7 maka Cohen's standard berada pada kategori sedang, dan apabila Effect size dari perhitungannya berada pada 0,2 sampai 0,4 maka Cohen's standard berada pada kategori rendah. Karena nilai dari effect cohn's d yaitu 1,1, Berdasarkan tabel interpretasi nilainya berada pada kategori tinggi dengan persentase sebesar $86 \%$.

\section{Saran}

Berdasarkan kesimpulan diatas dalam penelitian ini, maka peneliti mengemukakan beberapa saran sebagai berikut :

a. Bagi sekolah, diharapkan dapat menerapkan model pembelajaran kooperatif tipe co-op co-op dalam proses pembelajaran untuk menciptakan keaktifan peserta didik di dalam kelas baik pada mata pelajaran matematika maupun mata pelajaran lainnya.

b. Bagi pendidik yang ingin menerapkan model pembelajaran kooperatif tipe co-op co-op dapat berkreasi dalam membangkitkan keaktifan peserta didik agar model yang diterapkan tersebut lebih bermakna dan menyenangkan bagi peserta didik, selain itu pendidik harus memperhatikan alokasi waktu pembelajaran agar semua aspek pembelajaran dapat terlaksana dengan baik.

c. Bagi peneliti selanjutnya, disarankan untuk melakukan penelitian dengan pendekatan yang berbeda dan menerapkan model pembelajaran kooperatif tipe co-op co-op pada materi yang lebih kompleks.

\section{DAFTAR PUSTAKA}

Emzir. (2011). Metodologi Penelitian Pendidikan Kuantitatif \& Kualitatif. Jakarta: PT Rajagrafindo Persada.

Erhadap, E. (2017). Pengaruh Model Pembelajaran Kooperatif Tipe Cooperation in Education (Co-Op Co-Op) tarhadap Kemampuan Pemecahan Masalah Matematis Siswa pada Materi Kubus dan Balok. Jurnal Pendidikan Matematika Indonesia, 2, 19-26. 
Maryanti, S. (2018). Penerapan Model Pembelajaran Kooperatif Co-Op Co-Op Dengan Pendekatan Poe (Predict-ObserveExplain) Untuk Meningkatkan Kemampuan Pemecahan Masalah Matematis Siswa. Skripsi tidak dipublikasikan. Lampung: Universitas Islam Negeri Raden Intan.

Sugiyono. (2009). Metode Penelitian Administrasi Dilengkapi dengan Metode $R \& D$. Bandung: Alfabeta.

(2011). Metode Penelitian
Pendidikan (Pendekatan Kuantitatif,
Kualitatif, dan R\&D). Bandung: Alfabeta.

Wahyudi dan Anugraheni, I. (2017). Strategi Pemecahan Masalah Matematika. Diponegoro: Satya Wacana University Press. 